\title{
New Post Graduate Diploma in Education (PGDE) Students' Perceptions on ODL Teacher Education Programmes
}

\author{
Professor Richard Bukaliya \\ Zimbabwe Open University \\ Mashonaland East Region, Marondera \\ bukaliar@gmail.com
}

\author{
Barnabas Muyengwa \\ Zimbabwe Open University, \\ National Centre, Mount Pleasant, Harare \\ muyengwabb@gmail.com
}

\begin{abstract}
This study was carried out to establish new PGDE students' perceptions on ODL teacher education programmes offered through the Zimbabwe Open University. It adopted a mixed approach to data collection and presentation in which both qualitative and quantitative paradigms were used. Interviews and questionnaires were used to solicit data from the respondents. The population for the study consisted of 110 new students enrolled in the Department of Teacher Development for the Post Graduate Diploma in Education programme. Out of this population, 50 made it into a sample that was selected through stratified random sampling according to gender. Results from the study show that students had an idea that ODL through ZOU did not provide lectures but tutorials. The respondents also noted that ODL was an effective means of providing staff development to teachers. Responses show that ODL graduates are indeed effective and the majority of respondents have first hand information on how ODL had assisted in the production of teachers in Zimbabwe. However, issues to do with inadequate time for learning and lack of contact between the students and between the student and the tutor were some of the drawbacks of the system. Some students expected more notes and more sources of information from the tutors. Balancing studies with social life was a challenge. Travelling for long distances to tutorials and services was another challenge. Cultural shock or confusion was a challenge since most were coming from a conventional institution background. The study recommended that there be fullfledged decentralisation of services to districts or and make provision for tutorials to all programmes that could be used to effectively capacitate teachers in teacher education programmes. There should also be the adoption of computer mediated platforms to complement the module currently in use. The study further recommended that there be enhanced communication platforms to include newsletters and short message services.
\end{abstract}

\section{INTRODUCTION}

The establishment of open and distance universities has provided a mechanism for large-scale programmes of initial teacher training but open learning model has remained for most educators at the fringes of educational practice (Perraton, 2010). To add to that, ODL has been viewed as playing second fiddle to the conventional system especially where teacher training and development are concerned. Zimbabwe has seen more and more conventional teacher training institutions coming to the fold. Coupled with this, has been the proliferation of several universities, some private and others state owned. It is being this background that most of the students enrolling for the Post Graduate Diploma in Education (PGDE) at the Zimbabwe Open University (ZOU) are coming from conventional universities and are about to experience ODL for the first time. That the students could have opted for ODL teacher development programmes could be for a number of reasons. The predominantly conventional background therefore, makes the students have a different understanding of the ODL mode of delivery.

The PGDE programme offered by ZOU is a three semester programme which consists of sixteen course modules that are aimed at equipping the trainee teacher with the requisite skills to become a qualified teacher. With the focus now being on attaining the required professional qualification through ODL, there are tendencies to have an unbalanced view of the ODL mode of delivery more so in light of the low opinion held about ODL by society (Kangai\& Bukaliya, 2011; Bukaliya \& Mubika, 2012). This study sought to establish the perceptions held by PGDE students on the ODL mode with a view to appreciate their understanding of the mode as an option for teacher development, benefits and challenges of the mode. The study also further sought to enhance the learners 'understanding of the ODL mode of delivery with the view to change their attitudes towards the mode they had chosen for their professional development. It would appear as though some have been forced by the threats from 
the Civil Service Commission (CSC), the public sector employer in Zimbabwe, to have all noncertificated graduates attain professional qualifications or be forced out of employment as teachers.

\section{Statement of the Problem}

There have been various options through which to study for the various students depending on the different characteristics of the same. Some opt for ODL while others opt for the conventional system. What then could have driven those students with qualifications obtained from conventional systems to opt for the ODL system? What could be their expectations of the new system as they seek new knowledge? Hence the study sought to establish new PGDE students' perceptions on ODL teacher education programmes offered through the Zimbabwe Open University.

\section{RESEARCH QUESTIONS}

The present study was guided by the following sub problems which stood as research questions:

i. What is the students' understanding of ODL?

ii. How do students perceive ODL as a mode of teacher development?

iii. What are the perceived benefits of undertaking a teacher education programme through ODL?

iv. How, in the students' view, can ODL be used to capacitate teachers in teacher education programmes?

v. What challenges, if any, are likely to be faced by new students in ODL teacher development programmes?

\section{REVIEW OF LITERATURE}

\subsection{An Understanding of the Concept ODL}

ODL has been regarded as the learning that reflects both the fact that all or most of the teaching is conducted by someone removed in time and space from the learner, and that the mission aims to include greater dimensions of openness and flexibility, whether in terms of access, curriculum or other elements of structure (UNESCO, 2002; Perraton, 2010). According to Perraton (2010), distance education is defined as an educational process in which a significant proportion of the teaching is conducted by someone removed in space and/or time from the learner. Open learning is an organised educational activity, based on the use of teaching materials, in which constraints on study are minimised in terms of access, or of time and place, pace, method of study, or any of these. "Open and distance learning" is used as an umbrella term to include both distance education and open learning. Therefore, mostly in use are open educational resources) OERs) which are defined as educational materials, made freely available through technology, for consultation, use or adaptation on a noncommercial basis (Perraton, 2010 Kauppinen, 2013; Pawlowski and Hoel, 2012). Perraton (2010) argues that students are able to work at a distance, without attending lessons at an institution; they submit assignments and get guidance from a tutor on what they have written; in some cases opportunities for face-to-face teaching and discussion are built into the system. This is necessitated by the existence of ICTs and other teaching and learning media and other platforms. Such is the system under which ZOU operates to provide education to the masses who might have been disenfranchised one way or the other. ZOU has had face to face tutorials for all its programmes in which students are required to attend three tutorials of two hours each per semester. However, students are provided with hard copies as well as soft copies of modules of all the registered courses. Soft copies are accessed on the MyVista platform upon logging onto the ZOU website.

\subsection{Related Studies on how Students Perceive ODL as a Mode}

Some studies have established and confirmed the effectiveness of distance education as a delivery mode of higher learning that has benefits which equal or exceed those qualifications obtained through the conventional system (Kangai and Bukaliya, 2011, Bukaliya and Mubika, 2012; Ojo and Olakulehin, 2006). While this is the case, a study by Nielsen and Tatto (1993) shows that ODL can be effective in some subjects or courses while not being beneficial in others. Nielsen et al (1993) established that face-to-face education had some advantage in Mathematics but not in languages. It follows that where students want to learn languages, they perceived ODL as a better mode. According to Perraton (2010), the unique features that make-up ODL institutions, such as open access, opportunity for flexible learning, provision of quality learning materials, the use of multi-media and ICTs entice prospective learners to enroll. 


\subsection{The Perceived Benefits of Undertaking a Teacher Education Programme through ODL?}

ODL has generally brought with it a number of benefits according to findings from previous research studies. Some studies (e.g Kangai and Bukaliya, 2011; Bukaliya and Mubika, 2012; Ojo and Olakulehin, 2006) point towards more relaxed entry point requirements in ODL and students having the opportunity of deferring programmes, and even examinations courses up until when they are ready. In some studies, greater freedom by ODL students to decide on a number issues has been seen to be one of the most benefit of ODL (Kangai and Bukaliya, 2011; Bukaliya and Mubika, 2012; Stewart, 1987). These studies among others have revealed that making such decisions is a preserve for the ODL student and those in conventional set ups are devoid of this privilege. As such, Stewart (1987) argues that management systems for the conventional systems are rigid and restrictive to the extent that there is no alternative for the learner than to do all that is presented at a particular time. This restriction might therefore force learners to opt for the ODL mode.

Despite the fact that there were a few tutorials held for the ODL learners, these tutorials were found to be as effective as the lecture methods used in the conventional system. At ZOU, for example, there were three tutorial sessions each held over two hours per semester per course (Kangai and Bukaliya, 2011; Bukaliya and Mubika, 2012). These were deemed adequate by both learners and tutors to the extent that results in the various programmes showed that most students were doing well in their courses. This goes to demonstrate that regardless of the time spent in contact between the tutors and learners, there is quality learning taking place and as a result as argued by Koch (1998), ODL learners earned higher grades than students in conventional versions of the same classes due to constant contact with the tutors on internet based platforms and through private arrangement contact time. In mitigation to the official limited time spent, it has been seen that access to tutors in ODL is not as limited as it is in the conventional system. A study by Hiltz (1998) has shown that ODL learners through online programmes provided better access to tutors. At ZOU the MyVista could also be a viable platform for accessing tutors and all course modules. With all these benefits in play, notwithstanding of course, some drawbacks in the mode of delivery, students perceived that they would get better grades than in a face-to-face course (Valenta, Therriault, Dieter and Mrtek; 2001).

Since ODL is predominantly the preserve for the elderly working folk, the mode has been seen to be attractive by many as it entails retaining one's job at the same time acquiring both experience and the professional qualification. The learners pursue their studies without withdrawing their services from the jobs (Sahoo and Khan; 1998; Chakwera and Saiti; 2005). The ZOU motto, "Earn While You Learn" could have enticed the prospective learners to enroll with the ODL University.

Most ODL institutions have marketed their programmes through preparing colouful and high quality modules and learning materials (Kangai and Bukaliya, 2011). That being the case it is logical to assume that the quality of material has appealed to the prospective learner. A study by Gujjar (2007) shows that students were of the opinion that ODL materials appealed to the needs of distance learners as they were of high quality. Coupled with high quality tutorials, students held favourable perceptions towards ODL (Gujjar; 2007; Kangai and Bukaliya, 2011; Bukaliya and Mubika, 2012).

For these and other reasons therefore, most studies have shown that students felt that the ODL courses were "more convenient" than traditional courses (Kangai and Bukaliya, 2010; Bukaliya and Mubika, 2012; Ojo and Olakulehin, 2006; Hiltz, 1998).

\subsection{Challenges Faced by New Students in ODL Programmes}

Negative perceptions have continued to be the main challenge for prospective students to take up studies with ODL institutions (Kangai and Bukaliya, 2011; Bukaliya and Mubika, 2012; Dede 1996; Harrison 2001 as cited in Peat and Helland, 2002). For example Perspective (2001) and Allsop (2008) have indicated that lower success rates in some courses, disqualifies distance education as a high quality option to traditional education. This therefore, implies that the dropout rates could be a signal to potential students that something is amiss with the mode of delivery and thus it becomes scary to enroll through ODL. Closely related to this, is social acceptance of ODL products, more so in employment. Pityana (2004) has argued that there is no universal appeal for distance education among would be learners and suspicions remain about the quality of qualifications acquired through distance education. In some instances employers have been misinformed about the perceived poor quality to 
the extent that some have become wary of hiring ODL graduates (Kangai and Bukaliya, 2011; Bukaliya and Mubika; Allsop, 2008).

Despite the belief that ODL if predominantly for the older generations, there are clear signs that the young generation is now moving towards ODL. That being the case, the young generation may find it tough to sail through their programmes. Some studies have established that younger students had difficulties, particularly when ODL programmes were offered online (CEDL 1999; Mastrian and McGonigle, 1997; Guernsey, 1998). They therefore, preferred face-to-face interaction (Larson, 1967). In line with this argument, concerns have also been raised on the use and availability Information Communication Technologies (ICT) especially in the African context where utilisation is hampered by unavailability as well as limited electric power (Kangai and Bukaliya, 2011; Bukaliya and Dzimano, 2011). These facilitate effective provision of ODL services.

\section{Methodology}

The present study adopted a mixed approach to data collection and presentation (Mertens, 2005). Both qualitative and quantitative paradigms were adopted. This enabled the use of interviews and questionnaires to solicit data from the respondents. Respondents within the ten kilometer radius from the regional centre were interviewed as these could be accessed within the shortest time possible. Those outside the stated perimeter were issued with questionnaires which they could respond to at their convenient time and submit them during the January to June 2015 tutorial session number two. The items on both instruments were similar.

\section{Population and Sample}

The population for the current study consisted of 110 new students enrolled in the Department of Teacher Development for the PGDE programme. Out of this population, 50 made it into a sample that was selected through the stratified random sampling according to gender. It was hoped that providing proportional representation in the sample through the gender variable would help balance the responses as perceptions would tend to differ from one sex to the other.

\section{Presentation and Discussion of Findings}

\subsection{Section A: Students` Understanding of ODL}

The instruments started off by asking the respondents their understanding of ODL. A variety of responses was given. Some of the responses are provided below:

Respondent 1: It is a study carried out while someone is at home and work without taking leave.

Respondent 2: Reading or studying on your own without lectures.

Respondent 3: It is learning while you work, earn and have time for other social responsibilities.

Respondent 4: It is knowledge acquired without students frequently attending lectures but being supplied with relevant material for their studies.

There is clear evidence that the majority of the respondents had an idea of what ODL entailed. At ZOU there are no lectures but students attend tutorials where they discuss with tutors in the various programmes. This idea is clearly raised in most of the responses as respondents are aware that ZOU does not provide lectures but tutorials. The perceptions by respondents of ODL concur with the definitions of ODL presented by various authorities (e.g Perraton, 2010; UNESCO, 2002).

When asked if they thought it was effective to staff develop teachers through ODL, the majority of the respondents agreed as indicated in the figure below:




Figure1. Responses on whether it is effective to staff develop teachers through ODL

When asked to explain their responses, some of the respondents had this to say:

Respondent 1: It is effective because teachers are given relevant material for studying purposes and there is adequate learning time.

Respondent 2: ODL improves teacher performance and service delivery as the teacher practices what he/she is learning.

Respondent 3: It is very effective to staff develop teachers through ODL mainly because it is usually impossible at the age of most teachers to enroll at a university on full time basis.

Respondent 4: It is effective as it allows a large number of untrained teachers to acquire relevant skills and knowledge without taking them out of the classroom.

Respondent 5: It is effective given the current harsh economic conditions which make most teachers unable to learn through the conventional system hence the need for ODL.

Respondent 6: It is effective because the content part and quality does not differ from that offered through the conventional system.

All the respondents seem to agree that ODL is an effective means of providing staff development to teachers. This is so for various reasons as implied in the responses that are provided verbatim above. These are the same sentiments that have been echoed in several previous studies (e.g Kangai and Bukaliya, 2011; Bukaliya and Dzimano, 2011 Bukaliya and Mubika, 2012; Dede 1996; Harrison 2001 as cited in Peat and Helland, 2002) where ODL has been seen to effective in the development of teachers.

Respondent were asked, basing from their experience in the schools, if the ODL mode of delivery had helped produce effective teachers. According to Figure 2 below, 39(78\%) indicated that it had helped to produce very effective teachers. To the contrary, only $11(22 \%)$ indicated their displeasure to the use of the ODL in producing teachers that are effective.

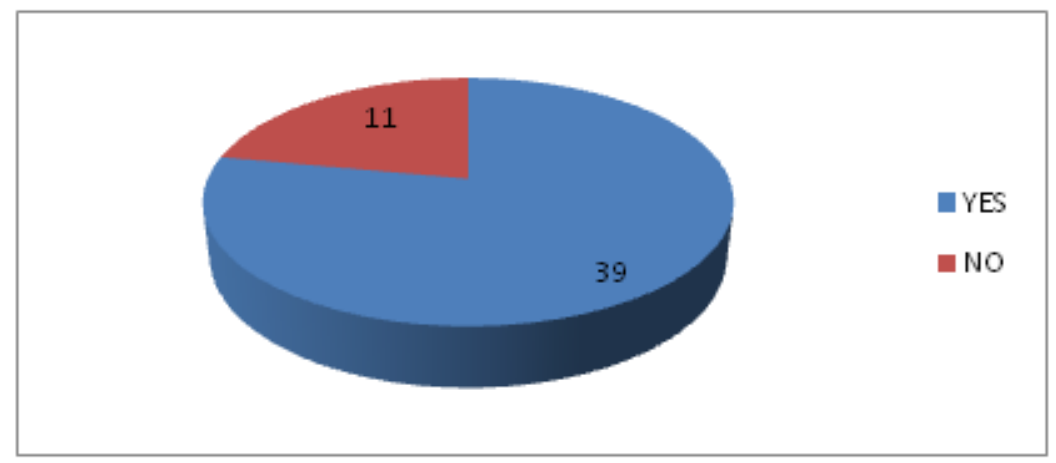

Figure2. Responses on whether the ODL mode of delivery had helped produce effective teachers in schools.

Respondents were asked to explain their responses to the question above and their responses are captured below:

Respondent 1: Yes. They are just as competent as conventionally trained teachers.

Respondent 2: Yes. Every day, the trainee teacher tries to implement what he/she has learnt or has read in the module and other materials.

Respondent 3: Yes. They are producing good results for all to see.

Respondent 4: Indeed the ODL mode of delivery has helped produce effective teachers as from my experience I have seen teachers developing and improving into quality and effective teachers after completing different programmes using the ODL mode.

These views imply that ODL graduates are indeed effective and the majority of responses seem to have first hand information on how ODL has assisted in the production of teachers in Zimbabwe. 
Those with reservations on the efficacy of the ODL delivery mode indicated issues to do with inadequate time for learning and lack of contact between the students and between the student and the tutor. While most of the new students knew about the ODL delivery mode, they were still hooked to the conventional system. This was all due to what Pityana (2004) established when some respondents indicated that they were still hooked to the conventional system. When asked what their expectations of the delivery mode were, the majority seemed to suggest that they expected their tutors to be delivering well thought out lessons and be able to provide comprehensive notes. One student remarked as follows:

We expect more notes and more sources of information from the lecturers. However, we do not doubt the quality of ODL mode offered by ZOU because at our workplace there are former students who have studied with ZOU. These are doing well and if the truth be told, they are our role models and we have learnt a lot from them.

The respondent was not aware that there were no lectures in ODL but face to face activities are refered to as tutorials. Their expectation of lectures was therefore misplaced and at most some of these learners ended up being frustrated because tutors only guided in ODL as opposed to the conventional system where a lot of activities had to do with lecturing. However, since there was the hardcopy module for use by ZOU students, no much fear was expected form the students as this provided a guide for the learners. Unlike in other studies (eg. CEDL 1999; Mastrian and McGonigle, 1997; Guernsey, 1998), the younger students had difficulties, particularly when ODL programmes were offered online. This was to be expected of the ZOU students but evidence at hand shows that most learning at $\mathrm{ZOU}$ is through the tutorials and the use of the module.

Most participants appreciated the ODL delivery mode. When asked if they would recommend someone to study with ODL for their staff development programme, the majority indicated that they would. The following were some of the forms of justification provided for by the various respondents:

Respondent 1: I have not had any disturbances in the life style that I had prior to joining the programme. One does not have leave his family to go and study through ODL.

Respondent 2: My family and social life are not disturbed by studies at ZOU. The other justification is that the employer does not have to cut my salary because I am still at work. I only have to take a few days off duty when I am going to sit for my examination.

Respondent 3: Most ODL students are mature and there appears to be a trend in the education system that all people in positions of power, both in government and in the private sector are from ZOU. It therefore motivates everyone to obtain qualifications through ODL.

When asked if they would want to register for another programme offered through ODL if they completed the current programme, most of the students were forthcoming and indicated that they would enroll for Masters degrees with ZOU owing to the numerous advantages they the envisaged to reap for their enrollment, an indication that the ODL mode was the mode of choice (Kangai and Bukaliya, 2011; Bukaliya and Mubika, 2012; Dede 1996; Harrison 2001 as cited in Peat and Helland, 2002; Perspective, 2001; Allsop, 2008). However, reservations were placed by some who indicated there were only a few post graduate masters programmes with ZOU that were recognised for teaching purposes by the Ministry of Primary and Secondary Education. ZOU only offered the Master of Education in Educational Management for teachers, hence only a few would venture into enrolling because of limited options.

\subsection{Section B: Students' Experiences with ODL in their Previous Studies}

The respondents were asked if they had studied through ODL in their previous studies. Figure 3, below shows the responses. 


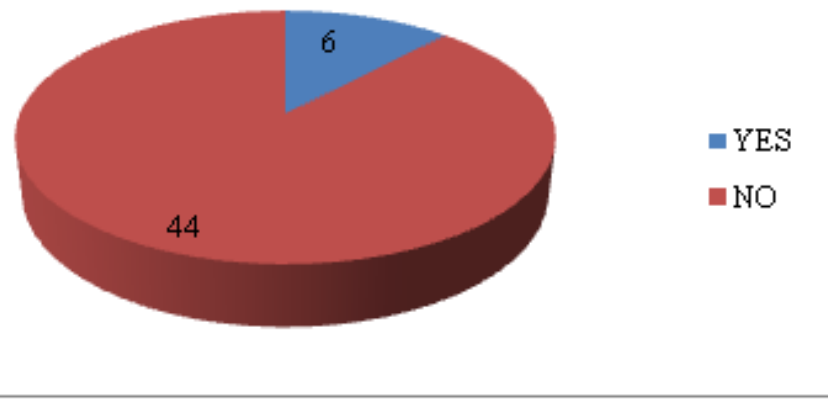

Figure3. Responses on whether the respondents had studied through ODL in their previous studies

Respondents were asked whether they successfully completed the programme they undertook through ODL. Out of the six, only three had successfully completed the programme, all of which were four year programmes. Respondents were further asked what they had admired most in the programme studied through ODL. The following are the responses from the three:

Respondent 1: The idea that I worked and at the same time learning was most admirable.

Respondent 2: I liked the idea that I could do my studies without having to forego other responsibilities and undertakings.

Respondent 3: I earned my degree without anyone knowing that I was enrolled for a programme. The secrecy in my studies was welcome thing as at my former workplace they discouraged people from learning.

There is clear evidence that most of the respondents admired the fact that through ODL one could get the needed qualifications without having to forego other duties and responsibilities.

Respondent were asked if there were any disappointments in the programme. From all the responses, it would appear that the respondents were not impressed by the isolation they had during their learning. One remarked that she was the only student in the district studying through ODL in which case discussions were out of question.

\subsection{Section C: Perceived Benefits of Undertaking a Teacher Education Programme through ODL}

Table1. Perceived benefits of undertaking a teacher education programme through $O D L$

\begin{tabular}{|c|c|c|c|c|}
\hline \multirow{3}{*}{ Expected Benefit } & \multicolumn{4}{|c|}{ Responses } \\
\hline & \multicolumn{2}{|c|}{ Agree } & \multicolumn{2}{|c|}{ Disagree } \\
\hline & No. & $\%$ & No. & $\%$ \\
\hline You study at your own convenience & 43 & 86 & 7 & 14 \\
\hline The use of modules benefits the learner & 46 & 92 & 4 & 8 \\
\hline There is tutor accessibility & 23 & 46 & 27 & 54 \\
\hline There is decentralisation of services to district centres & 32 & 64 & 18 & 36 \\
\hline Limited face to face so that students have more time for their own business & 28 & 56 & 22 & 44 \\
\hline You learn while you are at work & 50 & 100 & 0 & 0 \\
\hline $\begin{array}{l}\text { You are not subjected to salary deductions because you do not apply for } \\
\text { manpower development leave }\end{array}$ & 50 & 100 & 0 & 0 \\
\hline You do not leave your family or work place for extended periods of time & 50 & 100 & 0 & 0 \\
\hline You can register for courses you are able to pay for & 47 & 94 & 3 & 6 \\
\hline Flexible fees payment plan & 23 & 46 & 27 & 54 \\
\hline Generally, there is no change in one`s life style upon assuming studies & 33 & 66 & 17 & 34 \\
\hline
\end{tabular}

Table 1shows the perceived benefits of undertaking a teacher development programme through ODL. The table shows that $43(86 \%)$ agreed that it was beneficial in that they studied at their own convenience while some 46(92\%) agreed that the use of modules benefitted the learner. According to some $23(46 \%)$ there was tutor accessibility in ODL. However, some $27(54 \%)$ disagreed to the idea. Thirty-two (64\%) agreed that there was decentralisation of services to district centres and some 
$28(56 \%)$ agreed that there was limited face to face so that students had more time for their own business. Some 50(50\%) indicated that one learnt while they were at work. All 50(100\%) respondents indicated that they were not subjected to salary deductions because they did not have to apply for manpower development leave. According to another 50(100\%), one did not have to leave his/her family or work place for extended periods of time. Some 47(94\%) indicated one could register for courses they were able to pay for and to add to that, according to some 23(46\%), there was a flexible fees payment plan to cater for those who could pay fees in full at once. A majority of 33(66\%) agreed that generally, there was no change in one`s life style upon assuming studies. This is so in light of the view that ODL does not alter the lifestyle of learners as they are only required to attend tutorials on very occasions (Kangai and Bukaliya, 2011; Bukaliya and Mubika, 2012; Dede 1996; Harrison 2001 as cited in Peat and Helland, 2002; Perspective, 2001; Allsop, 2008), three times per semester, in the case of ZOU

\subsection{Section D: Challenges Likely to be Faced by New Students in ODL Teacher Development Programmes}

Table2. Challenges likely to be faced by new students in ODL teacher development programmes

\begin{tabular}{|l|l|l|l|l|}
\hline \multirow{2}{*}{ Anticipated Challenges } & \multicolumn{2}{l|}{ Responses } & \multicolumn{2}{l|}{ Disagree } \\
\cline { 2 - 5 } & Agree & No. & $\%$ \\
\cline { 2 - 5 } & No. & $\%$ & 27 & 54 \\
\hline Balancing studies with work & 23 & 46 & 25 & 50 \\
\hline Balancing studies with social life & 25 & 50 & 16 & 32 \\
\hline Travelling for long distances to tutorials and services & 34 & 68 & 5 & 10 \\
\hline Absence of health insurance for students in ODL & 45 & 90 & 8 & 16 \\
\hline Isolation of student from others & 42 & 84 & 11 & 22 \\
\hline Cultural shock/confusion & 39 & 78 & 17 & 34 \\
\hline Adjustment & 33 & 66 & 45 & 90 \\
\hline Lack of acceptance by prospective employers & 5 & 10 & 45 \\
\hline
\end{tabular}

Table 2 shows that 23(46\%) agreed that balancing studies with work was a challenge with the majority of $27(54 \%)$ disagreeing to the view. Balancing studies with social life was a challenge to $25(50 \%)$ with another $25(50 \%)$ disagreeing. However, 34(68\%) indicated that travelling for long distances to tutorials and services was a challenge and 16(32\%) disagreed. The absence of health insurance for students in ODL was a challenge to the majority of $45(90 \%)$ respondents while a minority of 5(10\%) did feel it was a challenge. According to $42(84 \%)$, isolation of student from others was a setback while 39(78\%) thought that cultural shock/confusion were a challenge. Thirty-three (66\%) agreed that adjustment was a challenge since they were coming from a conventional institution background. Some $5(10 \%)$ indicated lack of acceptance by prospective employers a point which some 45(90\%) disagreed with. Pityana (2004) established lack of social acceptance of ODL mode and some studies (eg. Kangai and Bukaliya, 2011; Bukaliya and Mubika2012; Allsop, 2008) established that some employers were misinformed about ODL delivery mode and were wary of employing ODL graduates. However, in the Zimbabwean context, it would now appear the Ministry of Primary and Secondary Education (MOPSE) is taking a leading role in accepting the ZOU graduates as these are being trained while on the job and besides studies by Kangai and Bukaliya (2011) and Bukaliya and Mubika (2012) have indicated that ZOU graduates were highly effective and were some of them held posts of responsibilities even before graduation.

\subsection{Section E: How ODL Can be used to Effectively Capacitate Teachers in Teacher Education Programmes}

Table3. How ODL can be used to effectively capacitate teachers in teacher education programmes

\begin{tabular}{|c|c|c|c|c|}
\hline \multirow[t]{3}{*}{ Strategy } & \multicolumn{4}{|c|}{ Responses } \\
\hline & \multicolumn{2}{|c|}{ YES } & \multicolumn{2}{|l|}{ NO } \\
\hline & No. & $\%$ & No. & $\%$ \\
\hline Full-fledged decentralisation of services to districts or clusters & 44 & 88 & 6 & 12 \\
\hline Adoption of computer mediated platforms to complement the module & 12 & 24 & 38 & 76 \\
\hline Improved payment plans for fee paying students & 34 & 68 & 16 & 32 \\
\hline University to offer grants, bursaries and other forms of sponsorship & 39 & 78 & 11 & 22 \\
\hline $\begin{array}{l}\text { To involve stakeholders to improve on visibility and acceptability of } \\
\text { programmes }\end{array}$ & 37 & 74 & 13 & 26 \\
\hline
\end{tabular}


New Post Graduate Diploma in Education (PGDE) Students' Perceptions on ODL Teacher Education Programmes

\begin{tabular}{|l|l|l|l|l|}
\hline New students to be inducted into the system & 35 & 70 & 15 & 30 \\
\hline Enhance communication platforms to include newsletters and sms & 33 & 66 & 17 & 34 \\
\hline
\end{tabular}

Table 3 shows that a majority of $44(88 \%)$ agreed that a full-fledged decentralisation of services to districts or clusters could be used to effectively capacitate teachers in teacher education programmes. To the contrary, only $6(12 \%)$ disagreed. The sentiments are true reflections as ZOU is not operating in all the districts. However, Mashonaland East Region has opened up district centres in Wedza, Chivhu and Murehwa. The adoption of computer mediated platforms to complement the module was received by only $12(24 \%)$ respondents. However, the majority of $38(76 \%)$ disagreed. Another majority of $34(68 \%)$ thought that improved payment plans for fee paying students was an effective strategy. Some $39(78 \%)$ indicated that the university should offer grants, bursaries and other forms of sponsorship to students like the case in the conventional systems. ZOU has roped in other agencies to assist in the payment of fees. For example there is EDULOAN, which provides loans for students and the MOPSE, through UNICEF is sponsoring some students in the teacher development programmers. Thirty-seven (74\%) suggested the involvement of stakeholders to improve on visibility and acceptability of programmes. New students to be inducted into the system, according to suggestions by $35(70 \%)$ while $15(30 \%)$ disagreed to the idea. Some $33(66 \%)$ agreed with the idea of enhancing communication platforms to include newsletters and short message services. However, some studies (e.g CEDL 1999; Mastrian and McGonigle, 1997; Guernsey, 1998) have advocated for the use of ICTs in communicating with students but in the African context utilisation of such is hampered by unavailability of these ICTs as well as limited electric power (Kangai and Bukaliya, 2011; Bukaliya and Dzimano, 2011).

\section{Conclusions}

Students have an idea that ODL through ZOU does not provide lectures but tutorials. The respondents also note that ODL is an effective means of providing staff development to teachers. Responses show that ODL graduates are indeed effective and the majority of respondents have first hand information on how ODL has assisted in the production of teachers in Zimbabwe. However, issues to do with inadequate time for learning and lack of contact between the students and between the student and the tutor are some of the drawbacks of the system. Some students expect more notes and more sources of information from the lecturers. Most participants appreciate the ODL delivery mode and indicated that they would recommend someone to study with ODL for their staff development programme and they were willing to register for another programme offered through ODL if they completed the current programme. There is clear evidence that most of the respondents admire the fact that through ODL one could get the needed qualifications without having to forego other duties and responsibilities. Mostly appreciated is the fact students learn while they are at work and are not subjected to salary deductions because they do not have to apply for manpower development leave. However, balancing studies with social life was a challenge. Travelling for long distances to tutorials and services was another challenge and ODL learners also needed health insurance for students in Cultural shock or confusion were a challenge as respondents indicated that adjustment was a challenge since they were coming from a conventional institution background.

\section{RECOMMENDATIONS}

From the findings, it is recommended that:

- There be full-fledged decentralisation of services to districts or clusters to include PIN number generation and provision of tutorials to all programmes that could be used to effectively capacitate teachers in teacher education programmes.

- There be the adoption of computer mediated platforms to complement the module currently in use.

- There be improved payment plans for fee paying students and that the university should offer grants, bursaries and other forms of sponsorship to students like the case in the conventional systems.

- There be the involvement of stakeholders to improve on visibility and acceptability of programmes.

- There be enhanced communication platforms to include newsletters and short message services. 
- More induction of new students is required so as to avoid cultural shock as students enroll into a new system altogether.

\section{REFERENCES}

Allsop, T. (2008). "Can Open and Distance Learning help make South Asia competitive?" in Education Research Journal, DFID, UK.

Bukaliya, R and Dzimano, P.R. (2011). Analysing Lecturers` Web/Internet Competence at the Zimbabwe Open University Published in the International Journal International Journal of Social Sciences and Education ISSN 223 - 4934 Vol. 1 Issue 4. 4 October, 2011. $\quad$ Pages 297312.

Bukaliya, R and Mubika, A.K (2012). Assessing challenges in the training of secondary school technical subject teachers through Open and Distance Learning ISSN: 2186-8492, ISSN: 21868484 Print Vol. 1. No. 4. November 2012

CEDL (1999). Students` attitudes towards distance learning. Distance Learning Abstracts [serial online]. Available at: http://www.lucent.com/cedl/stdtatt.html

Garland, M. R. (1993). Student perceptions of the situational, institutional, dispositional, and epistemological barriers to persistence. Distance Education.

Guernsey, L. (1998). Distance education for the not-so-distant. Chronicle of Higher Education [serial online].

Hellman, J. A. (2003). The Riddle of Distance Education: Promise, problems and applications for development. Geneva: United Nations Research Institute for Social Development

Hiltz, S. R. (1998). Impacts of college-level courses via asynchronous learning networks: some preliminary results. Journal of Asynchronous Learning.

Kangai, C.V and Bukaliya, R (2011). Teacher Development through Open and Distance Learning: The Case for Zimbabwe. Published in the International Journal on New Trends in Education, ISSN 1309 - 6249 Vol. 1 No. 3. October, 2010. Pages 79-93. (2011).

Keegan, D. (1996). Foundations of Distance Education (3rd Ed). London: Routledge.

Mastrian, K. G. \& McGonigle, D. (1997). Older student perceptions of technology based learning. On-Line Journal of Nursing Informatics. Downloaded from http://cac.psu.edu/ dxm12/percep2. html on 24 July 2015.

Ojo, D, A. \& Olakulehjin, F. K. (2006). "Attitudes and Perceptions of Students to Open and Distance Learning in Nigeria". International Review of Research in Open and Distance Learning Volume 7, Number 1. National Open University of Nigeria.

Olcott Jr., D. J. \& Wright, S. J. (1995). An institutional support framework for increasing faculty participation in post-secondary distance education. The American Journal of Distance Education.

Peat, J. \& Helland, K. (2002). Perceptions of Distance Learning and the Effects on Selection Decisions. Retrieved from: http://bus.utk.edu/iopsyc/pdf/Perceptions-of-Distance- Educationsiop2003.pdf on 26 July 2015

Perraton, H. (2010). Teacher Education: the Role of Open and Distance Learning, Vancouver, Commonwealth of Learning.

Richards, C. N. \& Ridley, D. R. (1997). Factors affecting college students' persistence in on-line computer managed instruction. College Student Journal [serial online]. December 1997

Russell, T. L. (1999). The no significant difference phenomenon. Raleigh: North Carolina State University.

UNESCO (2001). Teacher Education through Distance Learning Technology-Curriculum-Cost Evaluation Summary of Case Studies, Paris, UNESCO. 
AUTHORS' BIOGRAPHY

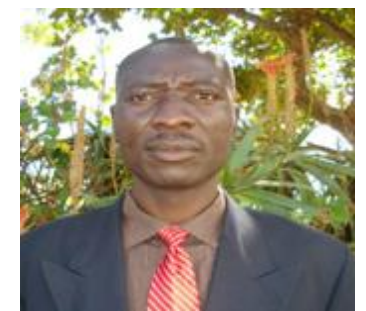

Richard BUKALIYA, is a Professor teaching at the Zimbabwe Open University in the Faculty of Arts and Education. He is the Regional Programme Coordinator in the Department of Teacher Development. His research interests include issues in Distance Education and Primary and Secondary education. The researcher has, to date, published several research articles in several international journals. He has presented papers at conferences locally and internationally. He is on the review boards of several international research journals which include the International Journal of Social Sciences and Education (IJSSE), The International Journal of Educational Research (JER), Greener Journals and the Global Research Journal of Education.



Mr. Barnabas Muyengwa is a Senior lecturer and National Programme Leader for the Bachelor of Education in Curriculum Studies and Post Graduate Diploma in Education (PGDE) in the Faculty of Arts and Education at the Zimbabwe Open University. He has published and reviewed articles in international peer reviewed journals. He has presented research papers at international and local conferences. 